\section{Venepunksjon mindre smertefullt enn hælprikking for blodprøver av nyfødte}

Illustrasjonsfoto: Colourbox.com

\section{Er venepunksjon mindre} smertefullt enn hælprikking ved blodprøvetaking av nyfødte?

\section{SYSTEMATISK OVERSIKT} prikking for blodprøvetaking av friske barn født til termin. Utfallene var neonatal smerterespons (vurdert ved hjelp av validerte målemetoder), mors angst, tid blodprøvetakingen tok og behov for å gienta prøvetaking.

\section{METODE} BASE/Excerpta Medica (til juni 2007); Cochrane Central Register of Controlled Trials (Issue 2, 2007); samt referanselister ble
Studier som ble inkludert sammenliknet venepunksjon med hæl-

Medline, CINAHL, and EM- gjennomsøkt for å finne randomiserte kontrollerte studie (RCT) eller kvasi-randomiserte studier. Fem studier $\quad(n=317$, 47 til 59 prosent gutter) møtte seleksion allokeringsprosedyre, ingen av studiene hadde blindet deltakere blindet i to RCT-er.

\section{OVEDRESULTATER}

Flere metoder for å måle smerter ble brukt; alle viste at neonata merterespons var lavere ved venepunksjon enn ved hælprikking (tabell). Èn RCT $(n=27$ viste at mors angst før prosedyren var høyere i venepunksjonsgrupmerte var lavere. Tid det tok for prøvetakingen var 58 sekunder engre for venepunksjon enn for prøver tatt i hælen i én RCT og 65 sekunder kortere $i$ en annen RCT challe ene hadde tilfredsstillende skjult pen, men maternell rangering av difference -36 sekunder, 95 prosent KI -76 til 3). Nyfødte i veneRCT, $\mathrm{n}=254$; relativ risiko 0,30 KI 0,13 til 0,49).

\section{KONKLUSJON}

KOnkre smertefullt en hælprikking ved blodprøvetaking av nyfødte.

Sammendrag fra: Shah V, Ohlson A. Venepuncture versus heel lance for blood sampling in term neonates. Cochrane 07;(4):CD001452. Korrespondanse: Dr V Shah, Mount Sinai Hospital, Toronto, Ontasiering.
(2 RCT-er, n=110; wighted mean punksjonsgruppen var mindre utsatt for gientatt prøvetaking (4 Finansieringskilde: ingen ekstern finan-
$\AA ̊$ ta blodprøver av nyfødte ved prikking i hælen er en smertefull prosedyre til tross for bruk av smertereduserende teknikker dre smertefullt alternativ. Denne og Ohlsson viste at venepunksjon prikking Likevel, de inkluderte prikking. Likevel, de inkluder på lansettene og nålene og det Venepunksjon kan være et minsystematiske oversikten av Shah er mindre smertefullt en hælstudiene rapporterte flere máter var opp til sju forksjellig perso- hælen og ikke å stikke i huden (1). ner som utførte prosedyrene. Likevel, denne smerten bidrar Ett viktig poeng er at tre validerte til total smerterespons ved hælmålemetoder ble brukt for å måle prikking når man sammenlikner smerterespons. «State of arou- de to intervensjonene.

sal» før stimuli er inkludert, både En subjektiv måling av mors angst Neonatal Infant Pain Scale og len trepunkts skala som ikke er Premature Infant Pain Profile, og validert) viste høyere angstnivå det er en styrke ved disse instru- ved venepunksjon. Likevel, dette mentene. Én studie somikke ble funnetkanvare feil og trengs a antene. Én sunnet kan vare fell og trengs a

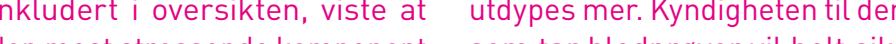
$\begin{array}{ll}\text { ved hælprikking var klemming av } & \text { som tar blodprøver vil helt sik- } \\ \text { varke antall hælprikk og }\end{array}$
TABELL: Neonatal respons med venepunksjon versus hælprikking ved blodprøvetaking av hyfødte*

\begin{tabular}{l|r|r|r|r|r}
\hline & $\begin{array}{r}\text { Vektet } \\
\text { «event rates» }\end{array}$ & $\begin{array}{r}\text { Vene- } \\
\text { punksjon }\end{array}$ & $\begin{array}{r}\text { Hæl- } \\
\text { prikking }\end{array}$ & $\begin{array}{r}\text { RRR } \\
(95 \% \text { KI) }\end{array}$ & $\begin{array}{r}\text { NNT } \\
\text { (KII) }\end{array}$ \\
\hline Utfall & $\begin{array}{r}\text { Antall } \\
\text { studier (n) }\end{array}$ & $44 \%$ & $76 \%$ & $42 \%(19$ til 59) & 4 (3 til 7) \\
\hline $\begin{array}{l}\text { Gråt innen } 60 \text { sek- } \\
\text { under ved punksjon }\end{array}$ & $1(117)$ & $56 \%$ & $96 \%$ & $42 \%(26$ til 54) & $3(2$ til 4) \\
\hline Gråt under prosedyre & $2(110)$ & $\begin{array}{r}\text { Weighted } \\
\text { mean values }\end{array}$ & & $\begin{array}{r}\text { Weighted mean } \\
\text { difference }\end{array}$ & \\
\hline & $2(81)$ & 2,0 & 3,9 & $-1,8(-2,6$ til $-1,1)$ & \\
\hline NIPS score** & $1(60)$ & 6,0 & 8,4 & $-2,5(-4,3$ til $-0,6)$ & \\
\hline PIPP score** & $1(50)$ & 44 & 156 & $-112(-164$ til -60)) & \\
\hline Tid første gråt & & & &
\end{tabular}

* Se forkortelser definert i ordlista Evidence Based Nursing online (http://ebn.bmj.com/current.dtl)

${ }^{*}$ NIPS, Neonatal Infant Pain Score; range of scores 0 til 7.

***PIPP, Premature Infant Pain Profile; range of scores 0 til 18. venepunksjoner som utføres vil fra alle studier at venepunksjon også påvirke prøvetakingstiden. Mer forskning er nødvendig for å vurdere effekten av opplæring av sykepleiere og andre involvert i påvirker smerte.

Shah og Ohlsson gir sykepleiere grunnlag for å støtte bruk av venepunksjon framfor hælprikking for a reduseme smerterved rutinemessig blodprøvetaking frorte til at barna gro̊t kortere tid begynte å gråte seinere og proporsjonen av barn som gråt var mindre. Forfatternes analyser antyder at ved å bruke venepunksjon i stedet for hælprikking, vil det for hver tredje prosedyre være behov for én mindre hælpunksjon, noe som ikke bare reduserer smerte, men ogsa traumer. prøvetaking og hvordan dette king for a redusere smerterved
Lindh V, Wiklund U, Håkansson S. eel lancing in term newborn infants: an analysis of heart rate variability. Pai 1999:80:143-8

- Evidence Based Nursing (EBN) vol 11. $\mathrm{hr} 3,2008$

Rosalie Mainous, ARNP, PhD, NNP-BC. University of Louisville, School of Nursing. Louisville, Kentucky, USA. 